\title{
The Effects of Emotional Labour, Job Characteristics and Job Demands on Job Burnout with Counterproductive Behaviour in Hermina Hospital Depok, West Java, Indonesia
}

\author{
Sera Causalita Utami Putri (Corresponding Author) \\ Faculty of Business \& Management \\ Universitas Pembangunan Nasional Veteran Jakarta, Indonesia \\ Iwan Kresna Setiadi \\ Faculty of Business and Management \\ Universitas Pembangunan Nasional Veteran Jakarta, Indonesia \\ Santoso Iman Mulyono \\ Faculty of Business and Management \\ Universitas Pembangunan Nasional Veteran Jakarta, Indonesia
}

Received: Oct. 8, 2021 Accepted: Nov. 8, 2021 Online published: Nov. 21, 2021

doi:10.5296/ijhrs.v11i4.19077～URL: https://doi.org/10.5296/ijhrs.v11i4.19077

\begin{abstract}
The quantitative research method is used in this research that aims to determine the effects of emotional labour, job characteristics and job demands on job burnout with counterproductive behaviour. The respondents in this research are nurses with a population of 160 . The size of the sample was taken as much as 100 respondents, with a probability sampling method specifically for simple random sampling. The questionnaire was used for data collection. The analysis technique used in this research is the analysis PLS (Partial Least Square) method. The results of this study indicate that (1) emotional labour has an effect on job burnout with a path coefficient of 0.751. (2) job characteristics have an effect on job burnout with a path coefficient of 0.231 (3) job burnout has an effect on counterproductive behaviour with a path
\end{abstract}


coefficient of 0.951 and (4) job demands have an effect on job burnout with a path coefficient of 0.687 .

Keywords: emotional labour, job characteristics, job demands, job burnout, counterproductive behaviour

\section{Introduction}

Hospital is one of the service industries engaged in health services that have strategic tasks and roles with an emphasis on recovery, healing, and efforts to improve patient health status. Employees are human resources who have an important element in an organization because employees carry out organizational activities so that employees who work in hospitals can provide good quality of human resources which are expected to run following organizational goals, namely having productive human resource management. Out of the various hospitals in Depok, there is the Hermina Hospital which is a hospital that specifically serves children's and women's health, obstetrics, and various other specialist service units. According to Skakon et al. (2010) job burnout is an important area of study because controlling stress and fatigue have been found to affect employee well-being and has become a common thing among health care employees with characteristics of the work environment such as high workloads or overtime work that can affect the work atmosphere and affect patient satisfaction. Maslach Burnout Inventory (MBI) defined job burnout as a symptom of emotional exhaustion, depersonalization, and decreased employee performance that can occur among individuals (Khan, 2013). The company's target that has not been achieved to reduce job burnout can be caused by several factors, including emotional labour which is a role demand that requires employees to hide the emotions they feel and display work emotions that are regulated in display settings as part of the service.

Another factor that can cause job burnout is job characteristics. By being given the diversity in work assignments, employees are expected to be able to motivate themselves to be able to improve their abilities, have responsibilities and knowledge related to the work carried out by employees and this triggers increased job burnout because of the many pressures and workloads. Furthermore, according to Robbins (2001), job characteristics is an attempt to identify the tasks of the job, how these characteristics are combined to form different jobs and the relationship with employee motivation, satisfaction and performance. Studies conducted by Schaufeli \& Bakker (2004) stated job demands are an obligation carried out by employees to be able to complete the amount of work given simultaneously in a brief time, employees are required to be able to manage the time and speed in completing the amount of work given. Job burnout is one of the factors that cause counterproductive behaviour, according to Chang \& Smithikrai (2010), counterproductive behaviour is a negative behaviour that originates from members of the organization which is seen by the organization as against their legitimate interests. Counterproductive behaviour has been described as deviant, antisocial behaviour, destructive and harmful behaviour that spreads and harms both the organization and the well-being of employees.

Based on further investigations where the interview was conducted with Mrs Ni Ketut Wiwik Widyawati as the HR Manager who manages the Education and Training Department at the 


\section{MInstitute ${ }_{\text {Ink }}^{\text {Macrothink }}$}

Hermina Hospital stated that once there were nurses who experienced uncomfortable treatment such as being scolded by doctors or patients and reprimanded by the head of the hospital unit because they did not come to work without permission and yet again decided not to come to work the next day, this is a form of counterproductive behaviour. Personality traits can also lead to counterproductive behaviour such as emotional instability felt by employees because of personal issues outside the office that make employees behave inconsistently with hospital regulations, decrease of work performance and subsequently employees who often do work incautiously can easily trigger counterproductive behaviour. Furthermore, Hermina Hospital has been instructed by the centre to think about how to reduce costs and increase revenue that should be implemented. The HRD is not allowed to increase revenue but emphasizes costs. One form of cost suppression is that Hermina Hospital streamlines the number of employees, if there are excessive employees the hospital shifts employees to units that lack manpower and the hospital does not want to add new employees because adding new employees means increasing costs with an estimated cost of IDR 4,000,000 to IDR $6,000,000$. In this case study, employees who work in hospitals experience high fatigue due to a large number of shift works and the amount of overtime that can lead to negative behaviours in forms of deviation such as anger which is sometimes difficult to control, provide unpleasant service to patients, create an ineffective work environment and establish a bad relationship with co-workers. Therefore, this study was aimed to identify possible reasons for emotional labour, job characteristics and job demands on job burnout with counterproductive behaviour and its relationship among nurses in Hermina Hospital. The specific objectives of the study are:

1. To identify possible factors that can affect job burnout and factors that are influenced by job burnout.

2. To analyze the factors which have significant effects on job burnout.

\subsection{Literature Review}

\subsubsection{Emotional Labour}

Karim \& Weisz explained Emotional labour is the process of planning, controlling and displaying the desired emotions required by the organization. Employees convey these emotions to patients through deep acting, surface acting and genuine emotions (as cited in Akhter, et al., 2016). Emotional labour requires employees to hide their personal feelings to show work emotions that exist in the organization by displaying display settings set by the organization as part of service performance. Furthermore, the performance of emotional labour requires that workers suppress their personal feelings to show the organizationally desirable work emotions by displaying organizationally specified "display rules" as part of their service performance, such as to "serve the customer with a smile" and/or to suppress negative emotions towards customers as part of the service performance (Igbojekwe, 2017, p. $3)$.

\subsubsection{Job Characteristics}

Schurman (2011) states the definition of job characteristics are aspects specific to a job, such 
as knowledge and skills, mental and physical demands, and working conditions that can be recognized, defined, and assessed that are important causes of employee health. Job characteristics as the core dimensions of work, namely the core dimensions of work are characteristics found in various types of work. Meanwhile, expressing perceived job satisfaction refers to job characteristics that determine the general nature as perceived by job holders (Hartiwi, 2016, p. 6).

\subsubsection{Job Demands}

Job demands denote to work prospects that take an individual to exert more psychological and physical efforts thus resulting in fatigue and strain. Job demands are categorized as some of the more challenging work aspects which could be from the work or the organization as well (Demerouti et al., 2001). Job demands stress out employees physical and mental capabilities which result in depleting their capabilities. This hence also results in making people work with lesser connectivity and energy (Schaufeli \& Bakker, 2004). Generally, job demands are catered to result in making employees becoming absent (Bakker et al., 2003); facing health problems (Hakanen et al., 2006). Seemingly, these studies have outlined that job demands can have a deleterious effect on employees in terms of their work outcomes and physical condition (as cited in Ahmed et al., 2017).

\subsubsection{Job Burnout}

Job burnout is considered the negative psychological state people experience when they are exposed to stress for a prolonged period. Burnout differs from stress in that burnout is deliberated as a prolonged presence of stress and is distinguished from depression in terms of the domain (Maslach et al., 1996). The concept of burnout had its origin in the study by Herbert Freudenberger (1974) who observed it as a state of energy depletion and loss of commitment and motivation among human service and healthcare volunteers which was associated with psychological and physiological symptoms. Physiological symptoms were present in the form of chronic headache and cold, sleeplessness, and weight loss among others. Since then, it has become an important topic that has been widely studied in various areas of occupations. Specifically, research on job burnout is heavily based on the conceptualization proposed by Maslach and colleagues who suggested that job burnout is a multidimensional construct consisting of three aspects: emotional exhaustion, depersonalization, and perceived lack of personal accomplishment (Charoensukmongkol, et al., 2016, p. 5).

\subsubsection{Counterproductive Behaviour}

Counterproductive behaviour is defined as such type of behaviour that disregards the norms of the rules of organization and its purpose is to harm the organization or people working their counterproductive behaviour can take different forms of violence, deviance, revenge, cyberloafing (Rehman, et al., 2017). Counterproductive behaviour is not only a single type of behaviour but also aggregated set of behaviours. By comparing it with a single type of behaviour, we come to know that counterproductive behaviours are more constant and valid regarding time/personality and situational variables (Lobnikar \& Pagon, 2014). Literature has 
shown that workplace shunning may result in depression and maladaptive (such type of behaviour does not provide adequate adjustment for suitable environment or situation. Shunning type of behaviour should be avoided in the organizations as research has shown that workplace aggression and counterproductive behaviour are positively related (as cited in Nawaz et al., 2018).

\subsection{Statement of the Hypotheses}

\subsubsection{Emotional Labor on Job Burnout}

Previous research done by Ma, Chen \& Tang (2010) indicated that job burnout is probably one of the most predictable consequences of emotional labour. In other words, employees in roles that are more emotionally demanding experience higher levels of fatigue than employees in roles that are less emotionally demanding. There are two types of theories to explain the relationship between emotional labour and job burnout. One of them is the action theory developed by Zapf (2002) which has found that there is a positive correlation between emotional labour and job burnout. The theory of action suggests that surface acting is a conventional activity, and does not require a lot of psychological resources. On the other hand, deep acting needs to use a lot of psychological resources because it is an internal cognitive process. This means that employees who control their emotions through deep acting can experience high levels of job burnout. Thus, employees who control their emotions through surface acting may experience more serious psychological conflict and higher levels of internal tension. Furthermore, Wu \& Shie (2017) indicated that deep acting plays a positive role in mitigating employees' job stress, while surface acting increases job stress by exhausting employees' emotional resources during service (Lee et al., 2015). Employees who are motivated to comply with organizational display rules and can understand and regulate emotions have a resulting reduction in job burnout. Thus, it is hypothesized that:

H1: There is a significant influence of emotional labour on job burnout.

\subsubsection{Job Characteristics on Job Burnout}

Based on the study conducted by Salami \& Ajitoni (2015) stated that emotional intelligence is chosen as a moderator which is a different factor from individuals who have the potential to prevent feelings of fatigue and also reduce the impact of unfavourable job characteristics on the onset of job burnout. Motivation is a force within a person that affects the goals, intensity, and persistence of employee behaviour in doing work. Individuals with high achievement motivation tend to be more ambitious, optimistic, have greater persistence and are more focused on achieving high-performance standards. Thus, individuals are more likely to have high self-esteem, increased morale, persistence, personal resources and overcome job characteristics that affect low job burnout. Several researchers have found a significant negative relationship between motivational factors and job burnout and used motivation as a moderator of the relationship between job characteristics and job burnout (Farzalipour et al, 2012). According to Ozbag \& Ceyhun (2014) stated emotional exhaustion is characterized by a lack of energy and individuals feel that they are emotionally overextended and exhausted at work. Cynicism refers to the development of negative, cynical attitudes and feelings about 
one's patients and excessively detached responses to other people at work. The third component of burnout, reduced personal accomplishment is the tendency to evaluate oneself negatively, particularly concerning one's work with patients or interactions with people at work. Various possible causes of burnout have been investigated and three categories including job characteristics, workload and role characteristics are identified as factors contributing to job burnout (Chen et al, 2012, p. 805). Thus, it is hypothesized that:

$\mathrm{H} 2$ : There is a significant influence of job characteristics on job burnout.

\subsubsection{Job Demands on Job Burnout}

According to Hakanen et al. (2008), Job demands are stressors in a situation that involves high efforts endured to achieve the expected performance level. Employees need to invest more resources to meet the demands and to protect themselves from further depletion. Maslach (1993) stated that burnout is caused by high job demands that drain the employee's energy, and in an attempt to cope with the resulting burnout, the employee withdraws mentally. Several studies investigating burnout show that burnout is related to job demands, such as time pressure and work overload. This is because giving too much for too long is energy depleting and this leads to burnout. For instance, when employees are burdened with a heavy workload for a sustained period, the energy required to perform their tasks would be depleting and this leads to burnout (Roslan et al., 2015, p. 3). Based on a study conducted by Baka (2015) stated previous researchers who examined the JD-R model proposed a new concept of the phenomenon of job burnout by defining it as the long-term effect of chronic work-related stress caused by high problems and poor job resources. The JD-R model is not only an emotional but also a physical and cognitive aspect. Instead of depersonalization i.e. maintaining emotional distance from employees which is defined as a distanced attitude with coworkers, and all work-related contexts such as work of the employee, work values, and organizational culture. Thus, employee exit from the organization is a broader notion, consisting of depersonalization and personal independence (Demerouti et al., 2001). Thus, it is hypothesized that:

H3: There is a significant influence of job demands on job burnout.

\subsubsection{Job Burnout on Counterproductive Behaviour}

According to Cropanzano et al. (2003) stated that based on resource conservation theory, if they feel that they lack sufficient resources to get the job done or their efforts fail to deliver the results the organization expects, employees become emotionally exhausted. Emotional exhaustion of employees can influence counterproductive behaviour through depersonalization such as emotional from individual work, consumers or co-workers and improper emotions within the organization. Furthermore, Liang \& Hsieh (2007) found a relationship between job burnout and counterproductive behaviour and found that depersonalization behaviour significantly predicts burnout, burnout and personal achievement cannot be predicted. A related study by Krischer et al. (2010) found that employees who reported being emotionally exhausted were more likely to display counterproductive behaviour. Other studies by Bolton et al. (2012) investigated the relationship between job 


\section{Macrothink Institute ${ }^{\text {TM }}$}

burnout (using the dimension of depersonalization) and counterproductive behaviour, They found that depersonalization significantly influenced counterproductive behaviour. However, concluded that the finding was consistent with the conservation of resources theory (Hobfoll, 1989), which argued that in a state of depleted emotional resources, heightened depersonalization increased the likelihood of counterproductive occurring. Uchenna (2013) conducted a study on the influence of perceived organizational support and job burnout on counterproductive behaviour showed that employees who reported job burnout showed a higher tendency of engaging in counterproductive behaviour than those who did not report job burnout. The present study uses the multidimensional construct of burnout-emotional exhaustion, depersonalization and low personal accomplishment to ascertain the unique contribution of each dimension in influencing employees' counterproductive behaviour (Ugwu, et al., 2017, p. 107). Thus, it is hypothesized that:

H4: There is a significant influence of job burnout on counterproductive behaviour.

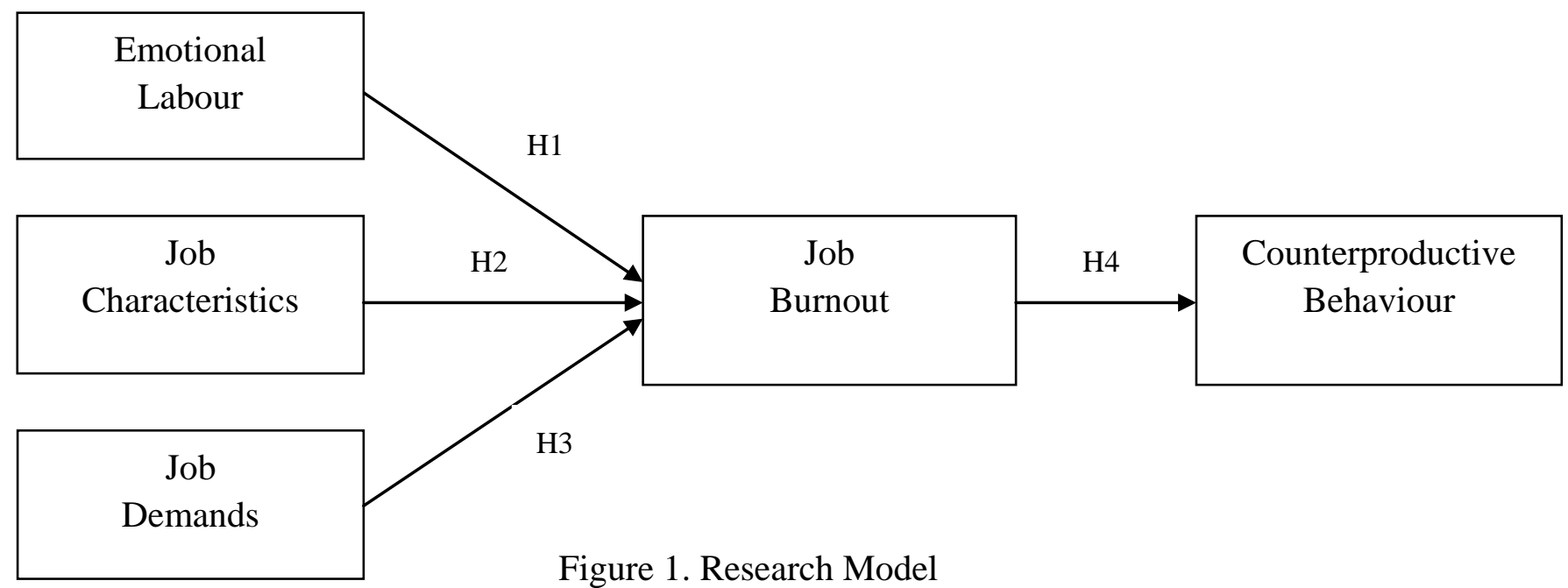

\section{Method}

\subsection{Research Design}

The associative quantitative method is used in this study to determine the effect of the relationship between variables and primary data obtained from respondents using a questionnaire in the form of structured statements that are qualified by using a Likert scale. According to Sugiyono (2013), the Likert scale is used to measure the opinions and attitudes of individuals or groups of people about social phenomena. Furthermore, these items are arranged according to a 5-point Likert scale (negative scores) where 1 indicates a response of very strongly agree, 2 indicates strongly agree, 3 indicates agree, 4 indicates disagree and 5 indicates very strongly disagree (Sugiyono, 2015). Data collected were analysed using smartPLS 3.

\subsection{Sampling Procedures}

Probability sampling is used for the sampling method in this study, specifically simple random sampling. According to Sugiyono (2017, p. 82), simple random sampling is taking 
the sample from the population that is carried out randomly without regard to the strata in the population. Respondents selected in this study were nurses with a population of 160 nurses

The research method used is Partial Least Square which is recommended to range from 30 to 100. According to Roscoe in Ferdinand (2011) stated that the sample size is found to be 25 times the independent variable. Furthermore, this study consists of 4 independent variables and 1 dependent variable, so the determination of the sample size is calculated from 4 independent variables, then the determination of the sample size is calculated from $4 \times 25=$ 100 respondents. Thus, the number of samples taken is 100 nurses at Hermina Hospital Depok.

\section{Results and Findings}

Based on data obtained in this study, of 100 respondents there were $92 \%$ female and $8 \%$ male nurses. This means that female respondents dominate because the Hermina Hospital previously only specialized in maternal and child care, then it was repositioned to become a General Hospital, therefore female nurses are believed to have more expertise in treating patients with patience and compassion. Female nurses understand patients better when complaints occur and handle problems well. The majority of respondents were aged between 26-30 years old (41\%), followed by respondents aged 20-25 years old (27\%), then aged 31-35 years old (19\%) and those aged above 35 years old (13\%). As for the timeline of work, the majority of respondents have experienced working for 4-6 years (43\%) which makes them fully competent at work, then 1-3 years of work (33\%) and above 6 years (24\%). Furthermore, there were divided into different work units, majority of the respondents were from the ICU unit with a percentage of $44 \%$ as ICU is more dominant because it needs a lot of nurses to be able to promptly help treat critical patients that possibly threaten patient safety if they are not given proper and fast treatment by nurses, followed by mother nursing no. 2 unit with a percentage of $19 \%$, mother nursing no. 1 unit with a percentage of $14 \%$, then general nursing unit with a percentage of $12 \%$, operation room unit with a percentage of $6 \%$ and newborn baby room unit with a percentage of $5 \%$. In terms of education level, the majority of respondents had received associate degrees with a percentage of $96 \%$ and followed by respondents with bachelor degrees with a percentage of $4 \%$. Hence, it can be said that nurses with associate degrees play a vital role in the nursing community and can either be a great starting point in nursing as students can take the degree when/where they want and also have an excellent and satisfying career ahead.

Subsequently, a discriminant validity test was done to analyse the average variance extracted (AVE) between the variables. Furthermore, a study conducted by Ghozali (2019) stated a questionnaire is said to be valid if the questions on the questionnaire can reveal something that will be measured by the questionnaire. A test is said to have high validity if the test performs a precise and accurate measurement function according to its purpose.

As presented in Table 1 shows the average variance extracted for independent variables and dependent variables. Results of the emotional labour $(\mathrm{AVE}=0.776)$, job characteristics (mean= 0.763), job burnout (AVE= 0.816), counterproductive behaviour (AVE= 0.725) and job demands $(\mathrm{AVE}=0.795)$ show AVE values for all variables are above 0.5 point as set for 
AVE to be valid as variable measuring instrument.

Table 1. Average Variance Extracted of All Variables

\begin{tabular}{lc}
\hline Variables & AVE \\
\hline Emotional Labour & .776 \\
Job Characteristics & .763 \\
Job Burnout & .816 \\
Counterproductive Behaviour & .725 \\
Job Demands & .795 \\
\hline
\end{tabular}

The next step after obtaining the validity of each instrument of question per variable is a reliability test. Table 2 shows that the values of composite reliability (CR) and Cronbach's alpha (CA) for all constructs are above 0.7 which indicates that all constructs in the estimated model meet the criteria. Based on the result obtained, emotional labour $(\mathrm{CR}=0.985, \mathrm{CA}=$ 0.9844), job characteristics ( $\mathrm{CR}=0.984, \mathrm{CA}=0.983)$, job burnout $(\mathrm{CR}=0.988, \mathrm{CA}=0.987)$, counterproductive behaviour $(\mathrm{CR}=0.980, \mathrm{CA}=0.979)$ and job demands $(\mathrm{CR}=0.987$, $\mathrm{CA}=0.985$ ). This reliability test leads to an understanding that the instrument used in the research is to obtain information that is used to be reliable as a data collection tool and can reveal actual information in the field.

Table 2. Composite Reliability and Cronbach's Alpha

\begin{tabular}{lcc}
\hline \multicolumn{1}{c}{ Variables } & CR & CA \\
\hline Emotional Labour & .985 & .984 \\
Job Characteristics & .984 & .983 \\
Job Burnout & .988 & .987 \\
Counterproductive Behaviour & .980 & .979 \\
Job Demands & .987 & .985 \\
\hline
\end{tabular}

Additionally, Table 3 shows that the magnitude of R Square (R2) of job burnout is 0.913, thus showing the effects of emotional labour, job characteristics and job demands on job burnout of $91.3 \%$ and the remaining $8.7 \%$ is influenced by other factors or other variables such as job satisfaction, workload and turnover intention. Thus, the R Square value for counterproductive behaviour is 0.904 , which means that job burnout affects counterproductive behaviour by $90.4 \%$ and the remaining $9.6 \%$ is influenced by other variables such as organizational justice and moral identity.

Table 3. Value of $\mathrm{R}$ Square $\left(\mathrm{R}^{2}\right)$

\begin{tabular}{ll}
\hline \multicolumn{1}{c}{ Variables } & $\mathrm{R}^{2}$ \\
\hline Job Burnout & .913 \\
Counterproductive Behaviour & .904 \\
\hline
\end{tabular}

Next, after the statement items per variable are declared valid, then all variables are also declared reliable and the research structural model is declared fit, thus it can be continued by conducting the t-statistical test of the study. The t-statistic test in this study, t-test or partial test is used to determine whether there is an effect between emotional labour, job 
characteristics, job demands on job burnout and job burnout on counterproductive behaviour. According to Sarjono \& Julianita (2011, p. 133) stated to find the t table value is obtained from the 0.05 significance level and the t table-level is obtained from $\mathrm{df}=$ number of samples - number of variables. Therefore, it is known that $\mathrm{t}$-table $=1.985$ which is obtained from the formula $\mathrm{df}=\mathrm{N}-\mathrm{K}$ or $\mathrm{df}=100-5=95$, then associated with an error degree of $5 \%$ or 0.05 . Furthermore, Ghozali (2016, p.97) stated that statistical tests (t-statistics) show how far the influence of an individual variable is in explaining the dependent variable. According to Sarjono \& Julianita (2013, p. 101) states that the basis for taking the hypothesis is:

a. If the probability value is less than or equal to the probability value of Sig. (0.05 sig.), H0 is accepted (Ha is rejected). That is, significant.

b. If the probability value is greater than or equal to the probability value Sig. (0.05 sig.), Ha is accepted (H0 is rejected). That is, not significant.

Based on the data obtained in table 4, the results of the testing hypothesis of emotional labour on job burnout show the $t$ value of $4.706>t$ table of 1.985 and the p-value of $0.000<0.05$, this shows that emotional labour has a significant effect on job burnout. Meanwhile, if the positive effect of emotional labour on job burnout can be obtained from the Original Sample of 0.751, which means that if the emotional labour is well, job burnout will decrease. Based on t count it is concluded that Ha1 is accepted and Hol is rejected. These results are relevant to the situation faced by nurses in hospitals, where good emotional control of work will reduce work fatigue. In carrying out emotional control, nurses must be able to motivate themselves and get used to displaying positive and sincere emotions when serving patients. Positive behaviour can help stabilize nurses' emotions and create a good work environment and establish good communication with coworkers and patients.

Furthermore, the results of the testing hypothesis of job characteristics on job burnout in table 4 show the $t$ value of $2.333>t$-table 1.985 and the $p$-value of $0.020<0.05$, this shows that job characteristics have a significant effect on job burnout. Meanwhile, a positive effect between job characteristics on job burnout can be obtained from the Original Sample of 0.231, based on t count it is concluded that $\mathrm{Ha} 2$ is accepted and $\mathrm{Ho} 2$ is rejected. These results are relevant to the situation at Hospital, where nurses are given independence in carrying out various jobs and responsibilities to achieve work results that have an impact on self-emotions and high work motivation. Nurses must be able to divide the time to do one job with another job and decide which job must be done first to achieve maximum work results.

Next, the results of the testing hypothesis of job burnout on counterproductive behaviour in table 4 show a t-value of $68.602>$ t-table 1.985 and a P-value of $0.000<0.05$, this indicates that job burnout has a significant effect on counterproductive behaviour. The positive effect of job burnout on counterproductive behaviour can be obtained from the Original Sample of 0.951. Based on $t$ count, it is concluded that Ha3 is accepted and Ho3 is rejected. These results are relevant to the situation at Hospital, where nurses feel low burnout in doing the work they are engaged in with high work productivity which can have an impact on decreasing counterproductive behaviour. 
Lastly, the results of the testing hypothesis of job demands on job burnout in table 4 show a t-count of $6.660>$ t-table of 1.985 and a P-value of $0.000<0.05$. This indicates that job demands have a significant effect on job burnout. The positive influence between job demands on job burnout can be obtained from the Original Sample of 0.687, which means that if the job demands are good, work fatigue will decrease. Based on t count, it is concluded that $\mathrm{Ha} 4$ is accepted and Ho4 is rejected. The results are relevant to Hospital, where nurses can use their skills well and display high work productivity and provide quality services. Due to this, nurses must be more active and focused in doing work using their skills so that they can be appreciated by the organization.

Table 4. Results of t-statistics

\begin{tabular}{llll}
\hline \multicolumn{1}{c}{ Variables } & $\begin{array}{c}\text { Original } \\
\text { Sample }\end{array}$ & t- statistics & P values \\
\hline Emotional Labour $\rightarrow$ Job Burnout & .751 & 4.706 & .000 \\
Job Characteristics $\rightarrow$ Job Burnout & .231 & 2.333 & .020 \\
Job Burnout $\rightarrow$ Counterproductive Behaviour & .951. & 68.602 & .000 \\
Job Demands $\rightarrow$ Job Burnout & .687 & 6.660 & .000 \\
\hline
\end{tabular}

\section{Discussion}

This study was obtained to describe the effects of emotional labour, job characteristics and job demands on job burnout with counterproductive behaviour. This study found that there is a significant relationship between these variables, emotional labour, job characteristics and job demands on job burnout with counterproductive behaviour. The results are obtained with variables that have a significant effect, namely emotional labour and job burnout, it is necessary to enhance the explanation of the dimensions and factors in each variable and there is a need for further research on the relationship between emotional labour and job burnout, which currently lacks a lot of research that has been done before. For emotional labour variables, it is necessary to create a comfortable working atmosphere and communication with coworkers and when serving patients to provide good quality services and achieve maximum work results. Nurses need to get used to displaying sincere emotions when caring for patients and controlling their emotions in any situation because providing services to patients is a top priority in their work as nurses, and also increases the friendliness when interacting in front of patients so that patients feel satisfied with the services provided not only to patients.

As for the variables of job characteristics and job burnout that have a significant effect, it is necessary to add a deeper theoretical explanation of each variable relationship by combining theories regarding the relationship between job characteristics and job burnout and also theories from other variables such as workload, job satisfaction and employee involvement that have a relationship with job burnout. The characteristics of the work need to be improved so that nurses feel responsible for making their own decisions about the work arrangements carried out so that nurses can feel appreciated by their superiors and feel they have high control over the work results to be achieved. Another thing that needs to be maintained is to manage time properly between doing one job and another so that nurses can further increase 
productivity and maximum work performance.

Furthermore, for the variables of job demands and job burnout that have a significant effect, it is necessary to enhance the explanation of theories regarding the relationship between the variables of job demands and job burnout in the discussion of hypotheses regarding the effect of the two variables that explain positive and negative effects and also add theory to the definition of job demands in a more complete manner and well understood by the researchers. Nurses need to increase the use of their work skills to the maximum, so nurses can effectively do their jobs and provide good quality of service and nurses can get used to completing work demands by the allotted time. Another thing that needs to be improved is teamwork within the work unit to be more effective in doing work simultaneously, especially in achieving harmony in the expected work results and the importance of relying on each other to help each other and share opinions.

Lastly, for variables that have a significant effect, namely job burnout and counterproductive behaviour, it is necessary to develop more research on questionnaire statements on the variables of job burnout and counterproductive behaviour due to the lack of complete statements to be used as reference sources in this study. Furthermore, it is necessary to increase work performance and productivity to be maximized because the most important task of nurses is to provide services to patients and nurses need to stabilize positive emotions to display these positive emotions and work behaviours. Another thing that needs to be improved is by creating a comfortable atmosphere when serving patients, such as ensuring that the patient room is always clean and tidy, communicating as clearly as possible to patients, always being alert in providing services when patients need help and the need for patients to be satisfied with the services provided by the hospital.

\section{Funding}

This research received no specific grant from any organization or funding agency.

\section{References}

Ahmed, U., Shah, M. A., Siddiqui, B. A., Shah, S. A., Dahri, A. S., \& Qureshi, M. A. (2017). Troubling Job Demands at Work: Examining the Deleterious Impact of Workload and Emotional Demands on Work Engagement. International Journal of Academic Research in Business and Social Sciences, 7(6), 2222-6990. http://doi.org/10.6007/IJARBSS/v7-i6/2949

Akhter, S. (2016). The Impact of Emotional Labor on Employee Performancewith Moderating Role of Supervisory Support. Department of Management \& Social Sciences. https://api.semanticscholar.org/CorpusID:203630557

Baka, L. (2015). Does Job Burnout Mediate Negative Effects of Job Demands on Mental and Physical Health in a Group of Teachers? Testing The Energetic Process of Job Demands-Resources Model. International Journal of Occupational Medicine and Environmental Health, 28(2), 335 - 346. http://dx.doi.org/10.13075/ijomeh.1896.00246

Bakker, A. B., Demerouti, E., De Boer, E., \& Schaufeli, W. (2003). Job Demands and Job Resources as Predictors of Absence Duration and Frequency. Journal of Vocational Behavior, 
62, 341-356. https://doi.org/10.1016/S0001-8791(02)00030-1

Bolton, L. R., Harvey, R. D., Grawitch, M. J., \& Barber, L. K. (2012). Counterproductive Work Behaviors in Response to Emotional Exhaustion: A Moderated Mediational Approach. Stress Health, 28(3), 22 -233. https://doi.org/10.1002/smi.1425

Chang, K., \& Smithikrai, C. (2010). Counterproductive behaviour at work: An investigation into reduction strategies. The International Journal of Human Resource Management, 21(8), 1272 -1288. https://doi.org/10.1080/09585192.2010.483852

Charoensukmongkol, P., Moqbel, M., \& Wirsching, S. G. (2016). The role of co-worker and supervisor support on job burnout and job satisfaction. Journal of Advances in Management Research, 13(1), 4-22. https://doi.org/10.1108/JAMR-06-2014-0037

Chen, H., Wu, P., \& Wei. (2012). New Perspective on Job Burnout: Exploring The Root Cause Beyond General Antecedents Analysis. Psychological Reports, 110(3), 801-819. https://doi.org/10.2466/01.09.13.PR0.110.3.801-819

Cropanzano, R., Rupp, D. E., \& Byrne, Z. S. (2003). The Relationship of Emotional Exhaustion to Work Attitudes, Job Performance, and Organizational Citizenship Behaviors. Journal of Applied Psychology, 88(1), 160-169. https://doi.org/10.1037/0021-9010.88.1.160

Demerouti, E., Bakker, A. B., Nachreiner, F., \& Schaufeli, W. B. (2001). The Job Demands-Resources of Burnout. Journal of Applied Psychology, 86, 499-512. https://psycnet.apa.org/doi/10.1037/0021-9010.86.3.499

Farzalipour, S., Ghorbanzadeh, B., Akalan, C., Kashef, M. M., \& Afroozeh, S. (2012). Motivation, satisfaction and burnout of volunteers in sport. Annals of Biological Research. 3(1), 684-692. http://scholarsresearchlibrary.com/archive.html

Ferdinand, A. (2011). Metode Penelitian Manajemen: Pedoman Penelitian untuk Penulisan Skripsi, Tesis, dan Disertasi (Edisi 3). Semarang: Badan Penerbit Universitas Diponegoro.

Freudenberger, H. J. (1974). Staff burnout. Journal of Social Issues, 30(1), 159-165. https://doi.org/10.1111/j.1540-4560.1974.tb00706.x

Ghozali, I. (2016). Aplikasi Analisis Multivariate dengan Program IBM SPSS 23 (Edisi 8). Badan Penerbit Universitas Diponegoro.

Hakanen, J. J., Bakker, A. B., \& Schaufeli, W. B. (2006). Burnout and Work Engagement among Teachers. Journal of School Psychology, 43, 495-513. https://doi.org/10.1016/j.jsp.2005.11.001

Hartiwi. (2016). Analisis Pengaruh Karakteristik Pekerjaan dan Kompetensi terhadap Kinerja Guru dengan Mediasi Kepuasan Kerja (Studi Pada SMP Muhammadiyah Se Kabupaten Pati). Semarang: Fakultas Pascasarjana, Universitas Stikubank Semarang.

Hobfoll, S. E. (1989). Conservation of Resources: A new attempt at conceptualizing stress. American Psychologist, 44(3), 513-524. https://doi/10.1037/0003-066X.44.3.513 
Igbojekwe, P. (2017). A Study of Emotional Labour Coping Strategies in Some Hotels in South East Nigeria. Journal of Hotel \& Business Management, 60(1), 2169-0286. http://dx.doi.org/10.4172/2169-0286.1000161

Khan, S. N. (2013). The Relationship between Job Burnout and Gender-Based Socio-Demographic Characteristics in Lahore. The Lahore Journal of Business, 1(2), 65-95. http://dx.doi.org/10.35536/ljb.2013.v1.i2.a4

Krischer, M. M., Penney, L. M., \& Hunter, E. M. (2010). Can Counterproductive Work Behaviors Be Productive? CWB as Emotion-Focused Coping. Journal of Occupational Health Psychology, 15(2), 154-166. https://psycnet.apa.org/doi/10.1037/a0018349

Lee, C., An, M., \& Noh, Y. (2015). The Effects of Emotional Display Rules on Flight Attendants' Emotional Labor Strategy, Job Burnout and Performance. Service Business, 9(3), 409-425. https://doi.org/10.1007/s11628-014-0231-4

Liang, S. C., \& Hsieh, A. T. (2007). Burnout and workplace deviance among flight attendants in Taiwan. Psychological Reports, 101(2), 457-468. https://doi.org/10.2466/pr0.101.2.457-468

Lobnikar, \& Pagon. (2014). Conflict, Bullying, and Counterproductive Work Behavior. The International Journal of Organizational Analysis. (No URL Found)

Ma, H., Chen, Y., \& Tang, H. (2010). Moderate Effect of Job Commitment on the Relationship between Employees' Emotional Labor and Burnout. International Journal of Digital Content Technology and its Applications, 4(9). https://doi.org/10.4156/jdcta.vol4.issue9.7

Maslach, C. (1993). Burnout: A multidimensional perspective. Professional burnout: Recent developments in theory and research, 19-32. https://doi/10.4324/9781315227979-3

Maslach, C. M., Jackson, S. E., \& Leiter, M. P. (1996). Maslach burnout inventory manual (3rd ed.). Palo Alto: Consulting Psychologist Press.

Nawaz, R., Ziaudin, M., Nadeem, M. T., \& Mohyud Din. (2018). The Impact of Psychopathy on Counterproductive Work Behavior. International Journal of Academic Research in Business and Social Sciences, 8(7), 208-220. http://dx.doi.org/10.6007/IJARBSS/v8-i7/4336

Ozbag, G. K., Ceyhun, G. C., \& Cekmecelioglu, H. G. (2014). The Moderating Effects of Motivating Job Characteristics on the Relationship between Burnout and Turnover Intention. Social and Behavioral Sciences, 150, 438- 446. https://doi.org/10.1016/j.sbspro.2014.09.048

Rehman, H. U., Idrees, H. H., \& Ullah, A. (2017). Organization and Usage of Information Resources at Deeni Madaris Libraries in Pakistan. Library Review, 66(3), 163-178. https://doi.org/10.1108/LR-02-2016-0016

Robbins, S. (2001). Perilaku Organisasi: Konsep, Kontroversi, Aplikasi (Jilid 1, Edisi 8). Prenhallindo, Jakarta. 
Roslan, N. A., Ho, J. A., Ng, S. I., \& Sambasivan, M. (2015). Job Demands \& Job Resources: Predicting Burnout and Work Engagement among Teachers. International Proceedings of Economics Development \& Research, 84. https://api.semanticscholar.org/CorpusID:56316119

Salami, S. O., \& Ajitoni, S. O. (2015). Job Characteristics and Burnout: The Moderating Roles of Emotional Intelligence, Motivation and Pay among Bank Employees. International Journal of Psychology. https://doi.org/10.1002/ijop.12180

Sarjono, H., \& Julianita, W. (2011). SPSS vs LISREL: Sebuah Pengantar, Aplikasi untuk Riset. Penerbit Salemba Empat, Jakarta.

Sarjono, H., \& Julianita, W. (2013). Spss Vs Lisrel: Sebuah pengantar, aplikasi untuk riset, Jakarta: Salemba Empat.

Schaufeli, W. B., \& Bakker, A. B. (2004). Job demands, job resources, and their relationship with burnout and engagement: A multi-sample study. Journal of Organizational Behavior, 25, 1-23. https://doi.org/10.1002/job.248

Schuurman, J. (2011). Job Characteristics, Health \& Satisfaction. Rotterdam: Netspar,

Skakon, J., Nielsen, K., Borg, W., \& Guzman, J. (2010). Are Leaders' Well-Being, Behaviours and Style Associated with The Affective Well-Being of Their Employees? A Systematic Review of Three Decades of Research. Work \& Stress, 24, 107-139. ttps://doi.org/10.1080/02678373.2010.495262

Sugiyono. (2013). Metode Penelitian Pendidikan Pendekatan Kuantitatif, Kualitatif dan R \& D. Alfabeta.

Sugiyono. (2015). Metode penelitian. Alfabeta.

Sugiyono. (2017). Metode Penelitian Kuantitatif, Kualitatif, dan R\&D. Alfabeta, CV.

Uchenna, C. O. (2013). Counterproductive Work Behavior among Employees in Emotionally Demanding Jobs: The Roles of Perceived Organizational Support, Job Burnout, and Age. Nigerian Journal of Applied Behavioural Sciences, 1, 105-114.

Ugwu, L. I., Enwereuzora, I. K., Fimbera, U. S., \& Ugwu, D. I. (2017). Nurses' burnout and counterproductive work behavior in a Nigerian sample: The moderating role of emotional intelligence. International Journal of Africa Nursing Sciences, 106-113. https://doi.org/10.1177/0046958017724944

Wu, X., \& Shie, A. J. (2017). The Relationship Between Customer Orientation, Emotional Labour and Job Burnout. Journal of Chinese Human Resource Management, 8(2), 54-76. https://psycnet.apa.org/doi/10.1108/JCHRM-03-2017-0005

Zapf, D. (2002). Emotion Work and Psychological Well-Being: A Review of The Literature and Some Conceptual Considerations. Human Resource Management Review, 12, 237-268. https://doi.org/10.1016/S1053-4822(02)00048-7 


\section{Copyright Disclaimer}

Copyright for this article is retained by the author(s), with first publication rights granted to the journal.

This is an open-access article distributed under the terms and conditions of the Creative Commons Attribution license (http://creativecommons.org/licenses/by/4.0/). 